\title{
Improving the Performance of Civil Servants: Evidence in Grobogan Regency, Indonesia
}

\author{
Isthofaina Astuty ${ }^{1, *}$ Satria Wicaksana Prabowo ${ }^{1}$ \\ ${ }^{1}$ Universitas Muhammadiyah Yogyakarta, Indonesia \\ *Corresponding author. Email: isthofainaastuty@umy.ac.id
}

\begin{abstract}
This Grobogan Regency is one of Central Java districts with low PAD (Regional Original Income) compared to other districts. It has resulted in the local government's low ability to provide benefits, so it is feared that it will affect civil servants' work motivation, which in turn impacts their performance quality that is not optimal. This condition is also worsened by several studies' findings, which reported that the leader's role was not optimal in providing work motivation to the civil servants in the Grobogan Regency. Therefore, this research is intended to identify the leadership role in influencing civil servants' performance and compensation of 25 SKPDs (Local Government Units) mediated by employee motivation. To measure the leadership variable, this research used a questionnaire from Hersey and Blanchard , the compensation variable questionnaire was adopted from Wibowo, the performance variable was from Gomes, while the motivation variable took the questionnaires from Mc Clelland. The analytical tool utilized was SEM with 140 samples. The analysis results revealed that leadership, compensation, and motivation influenced civil servants' performance in Purwodadi Sub-district, Grobogan Regency. Leadership was also reported to impact civil servants' work motivation, but compensation did not affect work motivation. Data analysis results also showed that the motivation variable did not become a mediating variable, which indicated that leadership and compensation directly influenced performance without going through employee's work motivation.
\end{abstract}

Keywords: Leadership, Compensation, Motivation, Employee Performance.

\section{INTRODUCTION}

Civil Servants (PNS) is a state apparatus with an essential role of government agencies in any parts of the cities and regions in Indonesia. On the other hand, civil servants also function to provide quality services to the public and other interested parties. However, civil servants in the Grobogan Regency have not shown their best performance, as reported by Suara Merdeka newspaper at 2015, which uncovered the number of civil servants in the Grobogan Regency who were absent during working hours and left their work on purpose. In the news, several civil servants were caught by raids held by the Central Java Provincial officers and the Grobogan Regency Public Order Enforcers (Satpol PP) in Disciplinary Operations. The raids were aimed at monitoring civil servants' discipline and promoting national disciplinary movements. Civil servants found absent during working hours were then recorded by the Badan Kepegawaian Daerah (Regional Civil Service Agency) and returned to their respective agencies to get sanctions. Similar things were also reported by [3], who researched at the Grobogan Regency Health Office. In her study, it was reported that employees who came to or left work not on time and did pointless things during working hours were frequent occasions. Employees often went out of the office during working hours for personal needs because the leaders were also often absent from the office. According to them, the leaders never took strict action against the employees' behavior and did not set an excellent example for his subordinates. This phenomenon indicated that the employees' performance was not optimal due to less high motivation.

On the other hand, less optimal performance is also influenced by less qualified leaders in managing their organizations. It is in line with the opinions of [17], who affirmed that one of the internal factors affecting performance is motivation. Besides, [14] also asserted that the motivation level was influenced by the factor of the employers' leadership style. Therefore, if the employer's leadership style is considered adequate by the 
employee, it would increase employee motivation, and in the end, it would improve employee performance. In line with this, the research results from [7], [20], [32] have proven that motivation positively and significantly affected employee performance.

Moreover, [22] defined leadership as the process of influencing or giving examples from the leaders to followers to achieve organizational goals, which directly affects employee performance. Thus, the way leaders behave to direct and give examples to subordinates will affect employees' performance. It is supported by several studies, such as research from [1], [12], which disclosed that it could increase motivation, performance, and job satisfaction.

Further, employees' less optimal performances are also influenced by the appreciation given by the company. When employees judge that their appreciations, which are tangible or intangible, both financial and non-financial, are considered reasonable in the form of salary or wage, they will show good performance. The same thing is stated by [25] that low performance causes limited funds, limited facility allowances, lack of effective management, and ineffective leadership systems. [34] admitted that the amount of compensation could affect employees' motivation. It is in accordance with [30], who also exposed that compensation significantly impacted motivation.

In addition to facing unfavorable work behavior problems from civil servants due to the lack of work motivation, the Grobogan Regency Government also encounters problems related to the ability to provide allowances to civil servants. Grobogan Regency has PAD (Regional Original Income) that is not too big compared to other Central Java cities. This condition will undoubtedly affect the allowance that will be obtained by Grobogan Regency civil servants, and, in the end, it is feared to cause a disparity between civil servants from one region to another, thus impacting civil servants' motivation and performance. Based on the lack of optimism in the leadership's roles and functions and the lack of civil servants' motivation and performance that still need to be improved, supported by conditions in the ability of the Grobogan Regency Government's PAD to provide appropriate benefits, this study was designed to identify the influence of leadership and compensation on civil servants' performance with motivation as an intervening variable.

This research is a modification of two previous studies. The first study was conducted to examine the influence of leadership, motivation, and work environment on 48 employees of Regional Offices Directorate General of State Assets of Suluttenggo and North Maluku in Manado. The second research was carried out to investigate the effect of leadership on 18 civil servants' performance in the Tagulandang Sub- district Office in Sitaro Regency. However, in this study, the researchers replaced or changed some of the previous research variables according to their needs.

Based on this background, the researchers wanted to examine further whether leadership, compensation, and motivation influence performance, with the research title "Improving Civil Servants' Performance: Evidence in the Grobogan Regency, Indonesia." The objectives to be achieved in this study are: To examine compensation's effect on motivation, motivation's effect on performance, leadership's effect on performance through motivation as a mediating variable, and compensation's effect on performance through motivation as a mediating variable.

\section{LITERATURE REVIEW}

\section{The Effect of Leadership on Motivation}

Siagian [23] argues that leadership is a person's ability to influence others; in this case, his subordinates, in such a way that they are willing to do the leader's will even though personally, it may not be pleasing for them. Besides, Terry [7] considers leadership an activity to influence people to work willingly to achieve common goals. It is stated that the situational leadership style is leadership that focuses on suitability or effectiveness in accordance with followers' maturity concerning specific tasks. The positive impacts of leadership in several previous studies, including research by [1], [12] are as follows: increasing work motivation, performance, and job satisfaction.

Furthermore, the leadership of a leader in an agency can influence one's motivation. If a leader can direct and guide his subordinates, employees will have high work motivation to work actively. Conversely, if the leader cannot direct and guide his subordinates, the employees' work motivation will be low so that the employees do not work hard and work actively. It is supported by [9] who stated that motivation from the leader to subordinates is essential. The research results from [3] also demonstrated that leadership affected the National and Political Unity Agency staff's work motivation in the South Kalimantan Province. Another study conducted by [18] also showed that leadership (transformational oriented leadership) had a significant effect on work motivation (public serviceoriented motivation). Likewise, the research from $[2,8,35]$ confirmed leadership's influence on employee motivation. Based on previous studies, both conceptually and empirically, the proposed hypothesis is as follows:

H1: Leadership has a positive and significant influence on motivation. 


\section{The Effect of Compensation on Motivation}

Compensation is the result of the selling of human resources for the company. The positive impacts of compensation according to several studies, some of them by $[28,29,30]$ are as follow: able to improve working motivation, able to improve performance, and able to improve the working satisfaction.

The compensation given by an institution can influence a person's motivation. Fair and proper compensation given to the employee would improve their motivation to work harder and strive for their workloads. On the contrary, if the compensation earned is not fair and proper, the employee's motivation would be low, so they do not work actively and do the work less enthusiastic.

Research conducted by [33] also proved that compensation significantly affected working motivation. Also, the research conducted by [4], [6], [10], [11], [16], [27] proved that compensation had a significant effect on working motivation. Based on the study upon prior studies, either conceptually or empirically, a hypothesis is proposed as follows:

$\mathrm{H} 2$ : Compensation has a positive and significant effect on motivation.

\section{The Effect of Motivation on Performance}

Usman [31] defines motivation as the employers' means to make their employees work harder and smarter as expected. The definition of motivation is stated by Sopiah as a situation where a person's effort and determination are directed towards specific achievement or goals. As [20] described, the positive impacts of motivation in some previous research are improving performance and working satisfaction.

Meanwhile, performance is the working output achieved by a person due to his or her work behavior in carrying out work activities. [19] specifies performance as the output notes taken from either production or specific works in a particular period. The performance impacts are target achievement, employee loyalty, training and development, promotion, positive behavior, and organizational improvement.

Further, motivation can influence employee performance in an institution. If a person has high motivation, he or she will make a dedicated effort in the work so that it results in high performance. In contrast, if a person has a low motivation, he or she will not strive for the work so that it ends up with a low working output. This fact is supported by several studies, which suggested that training and motivation would affect the improvement of employee performances, as in research by [5], [15], [17], [20], [24], [32], [36] . Based on the study upon prior research, either conceptually or empirically, a hypothesis was proposed as follows:
H3: Motivation has a positive and significant effect on performance.

\section{The Effect of Leadership on Performance throught Motivation as The Mediation Variable}

A nurturing and superintended leader will lead his or her employees to have high motivation to strive for their work and have high performance. On the contrary, if a leader fails to direct and guide, the employee will have low motivation, which results in low working enthusiasm and low performance. Such a statement is aligned with the research result [26], which proved that leadership affected performance through motivation. Based on the study upon prior research, either conceptually or empirically, a hypothesis was proposed as follows:

H4: Motivation has an effect as a mediation variable between leadership and performance.

\section{The Effect of Compensation on Performance throught Motivation as The Mediation Variable}

Proper and adequate compensation will make the employee able to fulfill their living needs so that they improve their motivation to work harder and diligently. Thus, high performance can take place. On the contrary, if the compensation earned is improper and insufficient, the employee motivation will be low, causing them to be unenthusiastic in working and low performance. A similar fact is proven by the research carried out by $[13,21]$. Based on the study upon prior research, either conceptually or empirically, a hypothesis was proposed as follows:

H5: Motivation has an effect as a mediation variable between compensation and performance.

Based on the five research hypotheses, a research model has been arranged, as illustrated in Figure 1 .

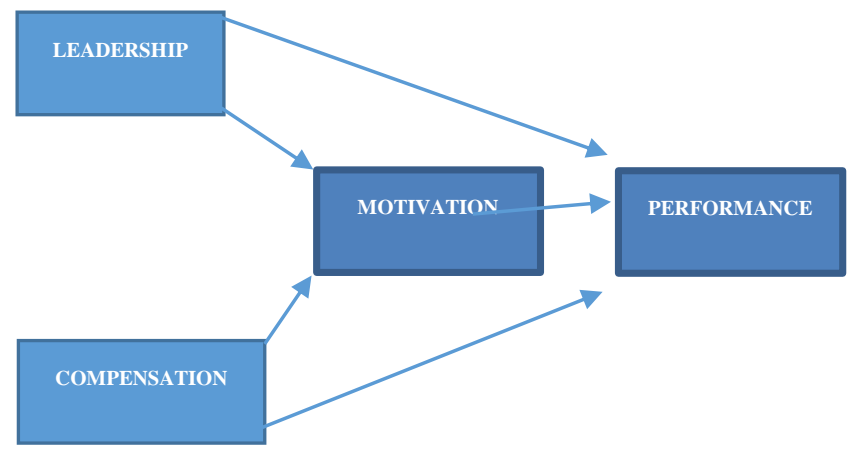

Figure 1: Research model

\section{METHODS}

There were 140 employees in this research derived from 25 SKPDs (Local Government Units) in Purwodadi Sub-district, Grobogan Regency. The performance instrument used was the instrument of Gomes (1995) with eight question items, leadership instrument by 
Hersey and Blanchard (1982) with 13 question items, compensation instrument by WIbowo (2011) with six question items, and motivation instrument by $\mathrm{Mc}$ Clelland with 20 question items. Meanwhile, the data analysis employed was SEM (Structural Equation Modeling).

\section{RESULT \& DISCUSSION}

\section{Result}

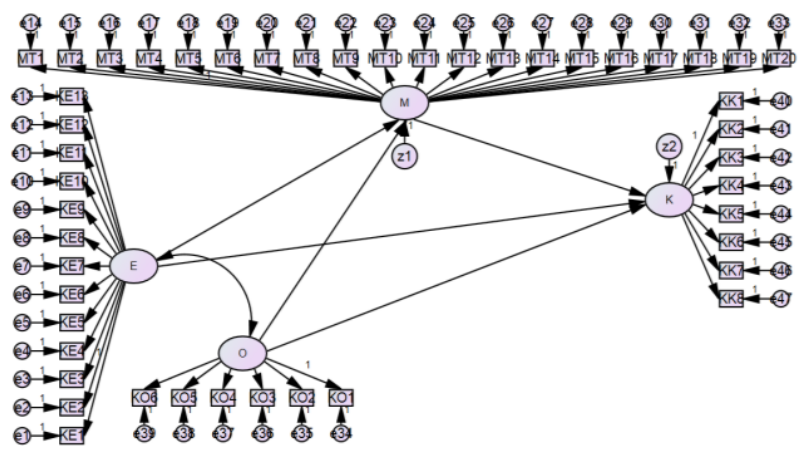

Figure 2: Relationship L, C,M and P

The validity and reliability test results revealed that all the instruments used were reliable, while several statistical validity tests fulfilled the standard. After the SEM assumption was carried out, and the assumptions were fulfilled, the next step was conducting a test employing several validity indexes to measure the proposed model. Based on figure 2 and table 1, it can be seen that two values were in accordance with the goodness of fit criteria, namely the aspect of CMIN/DF and RMSEA. Therefore, overall, the model could be considered as fit or suitable. Table 2 shows that based on the significance value, it could be considered that hypothesis 1 and hypothesis 2 were accepted. However, hypothesis 3 , stating that compensation has an effect on motivation, was denied. In other words, leadership affected motivation, and motivation influenced performance. Nevertheless, compensation did not impact motivation. The role of motivation as an intervening variable (or not) can be seen in Table 3 .

Table 1. Goodness Of Fit Index Result

\begin{tabular}{|c|c|c|c|}
\hline $\begin{array}{c}\text { The goodness } \\
\text { of fit Indices }\end{array}$ & $\begin{array}{c}\text { Cut of } \\
\text { value }\end{array}$ & \multicolumn{2}{|c|}{ Results } \\
\hline$X^{2}$-Chi-Square & $\begin{array}{c}\leq \\
1103,702\end{array}$ & 1610,912 & Not Fit \\
\hline Probability & $\geq 0,050$ & 0,000 & Not Fit \\
\hline CMIN/DF & $\leq 2,000$ & 1,567 & Fit \\
\hline GFI & $\geq 0,900$ & 0,697 & Not Fit \\
\hline AGFI & $\geq 0,900$ & 0,668 & Not Fit \\
\hline TLI & $\geq 0,900$ & 0,603 & Not Fit \\
\hline
\end{tabular}

\begin{tabular}{|c|c|c|c|}
\hline CFI & $\geq 0,900$ & 0,623 & Not Fit \\
\hline RMSEA & $\leq 0,080$ & 0,064 & Fit \\
\hline
\end{tabular}

Based on Table 3, it indicated that hypothesis 4 and hypothesis 5 were denied since the value of the indirect effect was less than the value of the direct effect. It denoted that the direct effect of compensation and leadership towards performance was higher than the indirect effect of compensation and leadership towards performance. Therefore, the effect of leadership and compensation on performance was not mediated by the motivation variable.

Table 2. Regression Weight Result

\begin{tabular}{|c|l|c|c|}
\hline No. & \multicolumn{1}{|c|}{ Hypothesis } & C.R. & P \\
\hline 1 & Leadership $\rightarrow$ Motivation & 2,213 & 0,004 \\
\hline 2 & Compensation $\rightarrow$ Motivation & 1,579 & 0,114 \\
\hline 3 & Motivation $\rightarrow$ Performance & 8,537 & 0,000 \\
\hline 4 & Leadership $\rightarrow$ Performance & 2,068 & 0,039 \\
\hline 5 & Compensation $\rightarrow$ Performance & 6,263 & 0,000 \\
\hline
\end{tabular}

Table 3. Standardized Direct And Indirect Effects Result

\begin{tabular}{|c|c|c|c|c|}
\hline & \multicolumn{2}{|c|}{$\begin{array}{l}\text { Standardized } \\
\text { Direct Effect }\end{array}$} & \multicolumn{2}{|c|}{$\begin{array}{l}\text { Standardized } \\
\text { Indirect Effect }\end{array}$} \\
\hline & Mot & Perf & Mot & Pert \\
\hline Compensation & 0,173 & 0,281 & 0,000 & $\mathbf{0 , 0 3 5}$ \\
\hline Leadership & $-0,075$ & 0,458 & 0,000 & $\overline{0,015}$ \\
\hline Motivation & 0,000 & 0,203 & 0,000 & 0,000 \\
\hline Performance & 0,000 & 0,000 & 0,000 & 0,000 \\
\hline
\end{tabular}

\section{Discussion}

The validity and reliability test results revealed that all the instruments used were reliable, while several statistical validity tests fulfilled the standard. After the SEM assumption was carried out, and the assumptions were fulfilled, the next step was conducting a test employing several validity indexes to measure the proposed model. Based on Table 1, it can be seen that two values were in accordance with the goodness of fit criteria, namely the aspect of CMIN/DF and RMSEA. Therefore, overall, the model could be considered as fit or suitable. Table 2 shows that based on the significance value, it could be considered that hypothesis 1 and hypothesis 2 were accepted. However, hypothesis 3, stating that compensation has an effect on motivation, was denied. In other words, leadership affected motivation, and motivation influenced performance. Nevertheless, compensation did not impact motivation. The role of motivation as an intervening variable (or not) can be seen in Table 3 . 


\section{CONCLUSION}

The research conclusions are a) leadership had an effect on motivation, b) motivation impacted performance, c) compensation did not have an influence on motivation, and d) the motivation variable did not mediate the effect of leadership and compensation on performance.

\section{ACKNOWLEDGMENTS}

The authors would like to thank all respondents who participated in taking their time and were willing to fill out the questionnaire for this study and also thanked the leadership of the freight forwarding company who had permitted so that this study could be carried out well.

\section{REFERENCES}

[1] [1] Agastia, N. P. A. (2014). Pengaruh Lingkungan Kerja Fisik, Komunikasi, dan Kepemimpinan terhadap Kinerja Karyawan PT. BPR Merta Sedana Badung. E-Jurnal Manajemen Universitas Udayana, 3(1).

[2] Al Rahbi, D., Khalid, K., \& Khan, M. (2017). The effects of leadership styles on team motivation. Academy of Strategic Management Journal.

[3] Apriliani, I. (2010). Hubungan Antara Persepsi Terhadap Gaya Kepemimpinan Transformasional Dengan Kinerja Pegawai Negeri Sipil Dinas Kesehatan Kabupaten Grobogan (PhD Thesis). Universitas Muhammadiyah Surakarta.

[4] Armanu, A., \& Sudjatno, S. (2017). The Effect of Direct and Indirect Compensation to Motivation and Loyalty of the Employee. Jurnal Aplikasi Manajemen, 15(1), 25-32.

[5] Chareonwongsak, K. (2017). Enhancing board motivation for competitive performance of Thailand's co-operatives. Journal of Co-operative Organization and Management, 5(1), 1-13.

[6] Dharma,P,S \& Achmad Sani, A, 2017, The Effect Compensation on Satisfaction and Employee Performance, Management and Economics Journal, Vol 1, Issue1, December 2017.

[7] Edy, S. (2009). Manajemen sumber daya Manusia. Jakarta: Kencana.

[8] Fiaz, M., Su, Q., \& Saqib, A. (2017). Leadership styles and employees' motivation: Perspective from an emerging economy. The Journal of Developing Areas, 51(4), 143-156.

[9] Hasibuan, M. S. (2010). Manajemen sumber daya manusia. Bumi Aksara.
[10] Karia, A. O., \& Omari, S. (t.t.). Importance of Compensation and Benefits on Performance of Public Water Utilities in Tanzania.

[11] Kautsar, M. A. K. (2017). Pengaruh Kompensasi Terhadap Peningkatan Kinerja Karyawan Di Pt Telkom Indonesia Regional Iv Jawa Tengah Dan Daerah Istimewa Yogyakarta, Bagian Infrastruktur. eProceedings of Management, 4(3).

[12] Kurniawan, A. W. (2018). Pengaruh Kepemimpinan Dan Pengembangan Sumber Daya Manusia Terhadap Kepuasan Kerja, Motivasi Kerja, Dan Kinerja Karyawan Bank Sulselbar. EKUITAS (Jurnal Ekonomi dan Keuangan), 16(4), 391-408.

[13] Lusiana, I., Anggraeni, S. K., \& Arina, F. (2015). Pengaruh Kompensasi Terhadap Kinerja Karyawan Melalui Motivasi Kerja dan Kepuasan Kerja Sebagai Variabel Intervening Menggunakan Structural Equation Modeling (SEM) (Studi Kasus di Divisi Produksi PT. XYZ). Jurnal Teknik Industri Untirta, $3(1)$.

[14] Mangkunegara, A. P., \& Prabu, A. (2009). Manajemen sumber daya manusia. Bandung: PT. Remaja Rosdakarya

[15] Nawaripi, M, 2017, Pengaruh Kepemimpinan dan Motivasi terhadap Kinerja Pegawai Pada Dinak Komunikasi dan Informeatika Provinsi Jawa Barat, Universitas Pasundan

[16] Ngatemin, W. A. (2012). Pengaruh Kompetensi Dan Kompensasi Terhadap Motivasi Kerja dan kinerja Karyawan Hotel Di Kabupaten Karo Provinsi Sumatera Utara. Jurnal Riset Akuntansi Dan Bisnis Vol 12 No. 2/September 2012.

[17] Octaviannand, R., Pandjaitan, N. K., \& Kuswanto, S. (2017). Effect of Job Satisfaction and Motivation towards Employee's Performance in XYZ Shipping Company. Journal of Education and Practice, 8(8), 72-79.

[18] Park, S. M., \& Rainey, H. G. (2008). Leadership and public service motivation in US federal agencies. International public management journal, 11(1), 109-142.

[19] Pereira, C. M., \& Gomes, J. F. (2012). The strength of human resource practices and transformational leadership: Impact on organisational performance. The International Journal of Human Resource Management, 23(20), 4301-4318.

[20] Potu, A. (2013). Kepemimpinan, motivasi, dan lingkungan kerja pengaruhnya terhadap kinerja karyawan pada Kanwil Ditjen Kekayaan Negara Suluttenggo dan Maluku Utara di Manado. Jurnal 
EMBA: Jurnal Riset Ekonomi, Manajemen, Bisnis dan Akuntansi, 1(4).

[21] Rini, R., Dibyantoro, D., \& Ardianto, M. I. (2014). Pengaruh Kompensasi Terhadap Kinerja Karyawan Melalui Motivasi Kerja Sebagai Variabel Intervening (Studi Pada Karyawan PT Duta Oktan Semesta Palembang), ORASI BISNIS,12(2)

[22] Rivai, V. (2009). Manajemen sumber daya manusia untuk perusahaan: Dari teori ke praktik. Rajawali Pers.

[23] Siagian, S. P. (2018). Teori motivasi dan aplikasinya. Rineka Cipta.

[24] Silic, M., \& Back, A. (2017, January). Impact of Gamification on User's Knowledge-Sharing Practices: Relationships between Work Motivation, Performance Expectancy and Work Engagement. In Proceedings of the 50th Hawaii International Conference on System Sciences.

[25] Simanjuntak, P. J. (2011). Manajemen \& evaluasi kinerja. Jakarta: Lembaga Penerbit Fakultas Ekonomi Universitas Indonesia.

[26] Susanto, Heri dan Nuraini Aisiyah. 2010. Analisis Pengaruh Kepemimpinan dan Budaya Kerja dengan Motivasi sebagai Variabel Intervening terhadap Kinerja Karyawan di Kantor Pertanahan Kabupaten Kebumen. Yogyakarta: Jurnal Magistra No. 74 XXII Desember 2010

[27] Tannady, H., \& Sitorus, T. (2017). Role of compensation, organization culture, and leadership on working motivation of faculty member (study case: Universities in North Jakarta). IOSR Journal of Business and Management, 19(10), 41-47.

[28] Thaief, I., \& Baharuddin, A. (2015). Effect of training, compensation and work discipline against employee job performance. Rev. Eur. Stud., 7, 23.

[29] Tulenan, S. (2015). The Effect of Work Environment and Compensation Toward Employee Performance at The Office of State Assets and Auction Service Manado. Jurnal EMBA: Jurnal Riset Ekonomi, Manajemen, Bisnis dan Akuntansi, 3(3).

[30] Ulfa, M. (2013). Pengaruh Kompensasi terhadap Motivasi Kerja dan Kinerja Karyawan (Studi pada Karyawan Auto 2000 Malang Sutoyo). Jurnal Administrasi Bisnis, 3(1).

[31] Usman,H, 2009, Manajemen:Teori, Praktik dan Riset Pendidikan, Jakarta Bumi Aksara

[32] Utomo, J. (2011). Suwardi.(2011). Pengaruh Motivasi Kerja, Kepuasan Kerja, dan Komitmen Organisasional terhadap Kinerja Pegawai (Studi pada Pegawai Setda Kabupaten Pati. Universitas Muria Kudus. Analisis Manajemen, 5 (1).

[33] Wekesa, J. N., \& Nyaroo, S. (2013). Effect of compensation on performance of public secondary school teachers in eldoret municipality Kenya. International Journal of Scientific and Research Publications, 3(6), 1-4.

[34] Yanuar, Y. (2017). Compensation, Motivation and Performance of Employees: Evidence from Indonesia. International Journal of Economic Perspectives, 11(4).

[35] Rindyantama, A. F., \& Astuti, R. J. (2017). Pengaruh Gaya Kepemimpinan, Loyalitas Karyawan, Dan Beban Kerja Terhadap Kinerja Karyawan (Studi pada Guru dan Karyawan UPT SMAN Nawangan Pacitan). Jurnal Manajemen Bisnis, 8(1), 52-81.

Dharmayati, A. S. (2015). Pengaruh Motivasi Intrinsik Dan Ekstrinsik Terhadap Kinerja Karyawan Dengan Kepuasan Kerja Sebagai Variabel Intervening Di Badan Pusat Statistik Provinsi Daerah Istimewa Yogyakarta. Jurnal Manajemen Bisnis, 6(2), 429. 450. 